\title{
Wobbly syndrome in an African pygmy hedgehog (Atelerix albiventris): neuropathological and immunohistochemical studies
}

\author{
Letícia Batelli de Oliveira ${ }^{1}$ Matheus Vilardo Lóes Moreira ${ }^{1}$ iD \\ Willian Henrique de Magalhães Santos ${ }^{1}$ Líslie Caroline Oliveira Stuart $^{1}$ Maria Dolors Pi Castro ${ }^{2,3}$ iD \\ Martí Pumarola Balle ${ }^{2,3}$ iD Roselene Ecco $^{1^{*}}$ iD
}

\begin{abstract}
${ }^{1}$ Setor de Patologia, Departamento de Clínica e Cirurgia, Escola de Veterinária, Universidade Federal de Minas Gerais (UFMG), Avenida Antônio Carlos, 6627, 31270-901, Belo Horizonte, MG, Brasil. E-mail: ecco@vet.ufmg.br. "Corresponding author.

${ }^{2}$ Mouse and Comparative Pathology Unit, Department of Animal Medicine and Surgery, Veterinary Faculty, Universitat Autònoma de Barcelona, 08193, Bellaterra, Barcelona, Spain.

${ }^{3}$ Networking Research Center on Bioengineering, Biomaterials and Nanomedicine (CIBER-BBN), Universitat Autònoma de Barcelona, 08193, Bellaterra,Cerdanyola del Vallès, Barcelona, Spain.
\end{abstract}

\begin{abstract}
A three-year-old female African pygmy hedgehog (Atelerix albiventris), born and domiciled in Brazil, presented apathy, prostration, and difficulty to stay standing. Its parents were siblings but did not present clinical signs related to this condition. As its clinical condition worsened, the animal was euthanized and referred for necropsy. No gross lesions were found in the central nervous system (CNS). Histologically, there was vacuolation with axonal degeneration in the white matter of the CNS and in peripheral nervous tissue. The KluverBarrera (KB) stain confirmed demyelination in vacuolated areas. Immunohistochemistry using several neural markers confirmed astrocytosis and microgliosis associated with vacuolated areas. In addition, there was a mild decrease in the immuno intensity of myelin proteolipid protein $(P L P)$ in these areas. These results suggest a genetic origin of the present demyelination, which resulted in the wobbly syndrome described in this report.
\end{abstract}

Key words: central nervous system, degenerative disease, myelopathy, vacuolation, histopathology.

\section{Síndrome de Wobbly em um ouriço pigmeu africano (Atelerix albiventris): estudo} neuropatológico e imuno-histoquímico

RESUMO: Um ouriço pigmeu africano de três anos de idade, nascido e domiciliado no Brasil, apresentou apatia, prostração e dificuldade em permanecer em estação. Os pais deste ouriço eram irmãos, mas não apresentaram sinais clínicos relacionados a esta condição. Com a piora dos sinais clínicos, o animal foi eutanasiado e encaminhado para necropsia. Não foram encontradas lesões macroscópicas no sistema nervoso central (SNC). Histologicamente, havia vacuolização com degeneração axonal na substância branca do SNC e no tecido nervoso periférico. A coloração de Kluver-Barrera (KB) confirmou desmielinização nas áreas vacuolizadas e a imuno-histoquímica utilizando vários marcadores, confirmou astrocitose e microgliose associadas com as áreas de vacuolização. Além disso, houve discreta diminuição da imunointensidade da proteína proteolipídica da mielina (PLP) nessas áreas. Estes resultados sugerem origem genética da desmielinização que resultou na síndrome de wobbly descrita neste relato.

Palavras-chave: sistema nervoso central, doença degenerativa, mielopatia, vacuolização, histopatologia.

The African pygmy hedgehog (Atelerix albiventris) is a mammal whose back is covered with thorns and originates from the African continent. Currently, they are raised as pets worldwide (GRAESSER et al., 2006). On average, the lifespan of these animals is four years, but they can reach 10 years in captivity (IVEY \& CARPENTER, 2012).

Wobbly syndrome (WS), also known as degenerative myelopathy or progressive paralysis is a neurodegenerative disease and has been described in this species. This disease usually occurs in young animals up to two years old; however, it can affect animals of any age. The early clinical signs are nonspecific, such as ataxia and incoordination, which gradually progresses to falls, usually to a single side, tremors, paresis or tetraparesis, scoliosis, muscular atrophy and exophthalmos (GRAESSER et al., 2006; LENNOX, 2007).

Grossly, there are no lesions in the central nervous system (CNS); however, diffuse muscle atrophy, an enlarged and pale liver, as well as areas of infarction in the renal cortex can be 
found (GRAESSER et al., 2006). Histologically, vacuolation in the white matter of the brain and the spinal cord as well as demyelination and axonal degeneration have been described. In chronic lesions, gliosis and neuronal necrosis can also be found (GRAESSER et al., 2006; LENNOX, 2007, DÍAZ-DELGADO et al., 2018).

The etiology is still unknown; however, genetic, nutritional and autoimmune etiologies have been suggested as possible causes of this disease (GRAESSER et al., 2006). The clinical, histopathological and immunohistochemical findings of WS in an African pygmy hedgehog (Atelerix albiventris) are described in this report.

A three-year-old intact female hedgehog, born and domiciled in Brazil presented apathy, prostration, and difficulty to stay standing. However, the ability to walk and sensitivity were still present. The animal was hand fed but was difficult to handle due to aggressive behavior. The onset of clinical signs started there are several weeks. As its clinical condition worsened, the owner elected to euthanize due to poor prognosis and the animal was referred for necropsy. Its parents were siblings but did not present clinical signs related to this condition.

Grossly, in the skin of the bilateral periocular region, there was alopecia with the formation of crusts. The animal had muscular atrophy, especially in the muscles of pelvic limbs.
The kidneys had irregular cortical surface and multifocal whitish millimetric areas in the cortex. The right kidney had moderate hydronephrosis. The brain, spinal cord, ganglia and trigeminal nerves, peripheral nerves of the members (including brachial plexus), eye, skeletal striated muscles and sections of all organs were collected and placed in $10 \%$ buffered formalin. The tissues were fixed for 52 hours, routinely processed, paraffin embedded, and sectioned at $4 \mu \mathrm{m}$ thickness for histological slide preparation. Subsequently, the slides were stained with hematoxylin and eosin and evaluated under white light microscopy. Selected slides of the central and peripheral nervous system were stained using the Kluver-Barrera (KB) method to detect myelin (normal or debris). The same tissues were also submitted to immunohistochemistry (IHC) for NSE, Nft, GFAP, Olig-2, Iba-1, and PLP (cell markers characteristics used for IHC are shown in Table 1). Anti-mouse (catalogue number $\mathrm{K}$ 4007; Dako Glostrup, Denmark) and anti-Rabbit (catalogue number K 011; Dako) En Vision ${ }^{\mathrm{TM}}$ kits were used as secondary antibodies. In all cases a 3,3' diaminobenzidine-based detection kit was used (Dako). Sections were counterstained with hematoxylin. Samples of respective regions from the brain of an age-matched hedgehog without neuropathological changes were also tested. For the negative control, an isotype-specific

Table 1 - Primary antibodies used for immunohistochemistry.

\begin{tabular}{|c|c|c|c|c|}
\hline Marker & Antibody name & $\begin{array}{l}\text { Manufacturer and } \\
\text { catalogue number }\end{array}$ & Dilution & Pretreatment \\
\hline GFAP & $\begin{array}{l}\text { Rabbit anti-bovine glial } \\
\text { fibrillay acidic protein }\end{array}$ & $\begin{array}{l}\text { Dako, Glostrup, } \\
\text { Denmark; Z0334 }\end{array}$ & $1: 5000$ & $\begin{array}{l}\text { Citrate buffer } 0.01 \mathrm{M} \mathrm{pH} 6.0,20 \mathrm{~min} \\
\text { water bath }+30 \mathrm{~min} \text { room temperature }\end{array}$ \\
\hline Iba-1 & $\begin{array}{l}\text { Goat polyclonal to Iba } \\
1\end{array}$ & Abcam, ab5076 & $1: 300$ & $\begin{array}{l}\text { Citrate buffer } 0.01 \mathrm{M} \mathrm{pH} 6.0,20 \mathrm{~min} \\
\text { water bath }+30 \mathrm{~min} \text { room temperature }\end{array}$ \\
\hline Neurofilaments (Nft) & $\begin{array}{l}\text { Mouse monoclonal } \\
\text { anti-NF } 200 \mathrm{kD}\end{array}$ & Sigma, N0142 & $1: 5000$ & $\begin{array}{l}\text { Citrate buffer } 0.01 \mathrm{M} \mathrm{pH} 6.0,20 \mathrm{~min} \\
\text { water bath }+30 \mathrm{~min} \text { room temperature }\end{array}$ \\
\hline $\begin{array}{l}\text { Neuron specific enolase } \\
\text { (NSE) }\end{array}$ & $\begin{array}{l}\text { Mouse monoclonal } \\
\text { anti-human }\end{array}$ & Dako, M0873 & $1: 600$ & $\begin{array}{l}\text { Citrate buffer } 0.01 \mathrm{M} \mathrm{pH} 6.0,20 \mathrm{~min} \\
\text { water bath }+30 \mathrm{~min} \text { room temperature }\end{array}$ \\
\hline Olig-2 & $\begin{array}{l}\text { Rabbit Olig-2 } \\
\text { polyclonal antibody }\end{array}$ & $\begin{array}{l}\text { Merck Millipore, AB } \\
9610\end{array}$ & $1: 500$ & $\begin{array}{l}\text { Citrate buffer } 0.01 \mathrm{M} \mathrm{pH} 6.0,20 \mathrm{~min} \\
\text { water bath }+30 \mathrm{~min} \text { room temperature }\end{array}$ \\
\hline PLP & $\begin{array}{l}\text { Mouse monoclonal } \\
\text { anti-Myelin proteolipid } \\
\text { protein }\end{array}$ & $\begin{array}{l}\text { Chemichon, MAB } \\
388\end{array}$ & $1: 300$ & No pre-treatment \\
\hline
\end{tabular}

GFAP: glial fibrillay acidic protein; Iba-1: Ionized calcium binding adaptor molecule 1; Olig-2: oligodendrocyte transcription factor 2; PLP: proteolipid protein. 
immunoglobulin was used as a substitute for the primary antibody; no immunostaining was detected in these sections.

Histologically, a moderate to marked status spongiosus of the nervous tissue was present in the CNS with a bilateral and symmetrical pattern affecting mainly the white matter. In the cerebrum (Figure 1A), the corona radiata and internal capsule were the most affected areas, and the adjacent gray matter structures (multiform layer of the cerebral cortex, basal nuclei) had a mild status spongiosus. In the cerebellum the status spongiosus was mild, affecting both hemispheres together with the vermis and cerebellar nuclei. In the brain stem (Figure 1B), the pons and the medulla oblongata had marked spongiosis in white matter tracts. Status spongiosus in the spinal cord was moderate in the cervical region, marked in the thoracic region and mild in the lumbar region. The status spongiosus were present mainly in the deep areas of the lateral funiculi. A mild amount of vacuolated spaces was also present in the gray matter.
In all areas aforementioned, the vacuoles were small to mid-sized, round to irregular, or confluent creating large spaces. In all cases, they were apparently empty, with mild axonal degeneration and multifocal gliosis. There were no changes in the neuronal bodies. In the trigeminal nerve and the nerves of the brachial plexus, there was dilatation of the myelin sheath, swelling and eosinophilia of the axon (Figure 1C).

Several myofibers of the pelvic limbs skeletal musculature had reduced sarcoplasmic size and irregular shape (anguloid fibers). Some contained multifocal basophilic mineralization foci. Other lesions found included moderate multifocal chronic lymphoplasmacytic interstitial nephritis, diffuse hepatic mild lipidosis, erosive glossitis and focal orthokeratotic hyperkeratosis.

Sections of the CNS stained by the KB technique revealed loss of myelin in areas of marked vacuolation (Figure 1D). For the IHC techniques performed on central and peripheral nervous tissue samples, neuronal markers (NSE and Nft) revealed

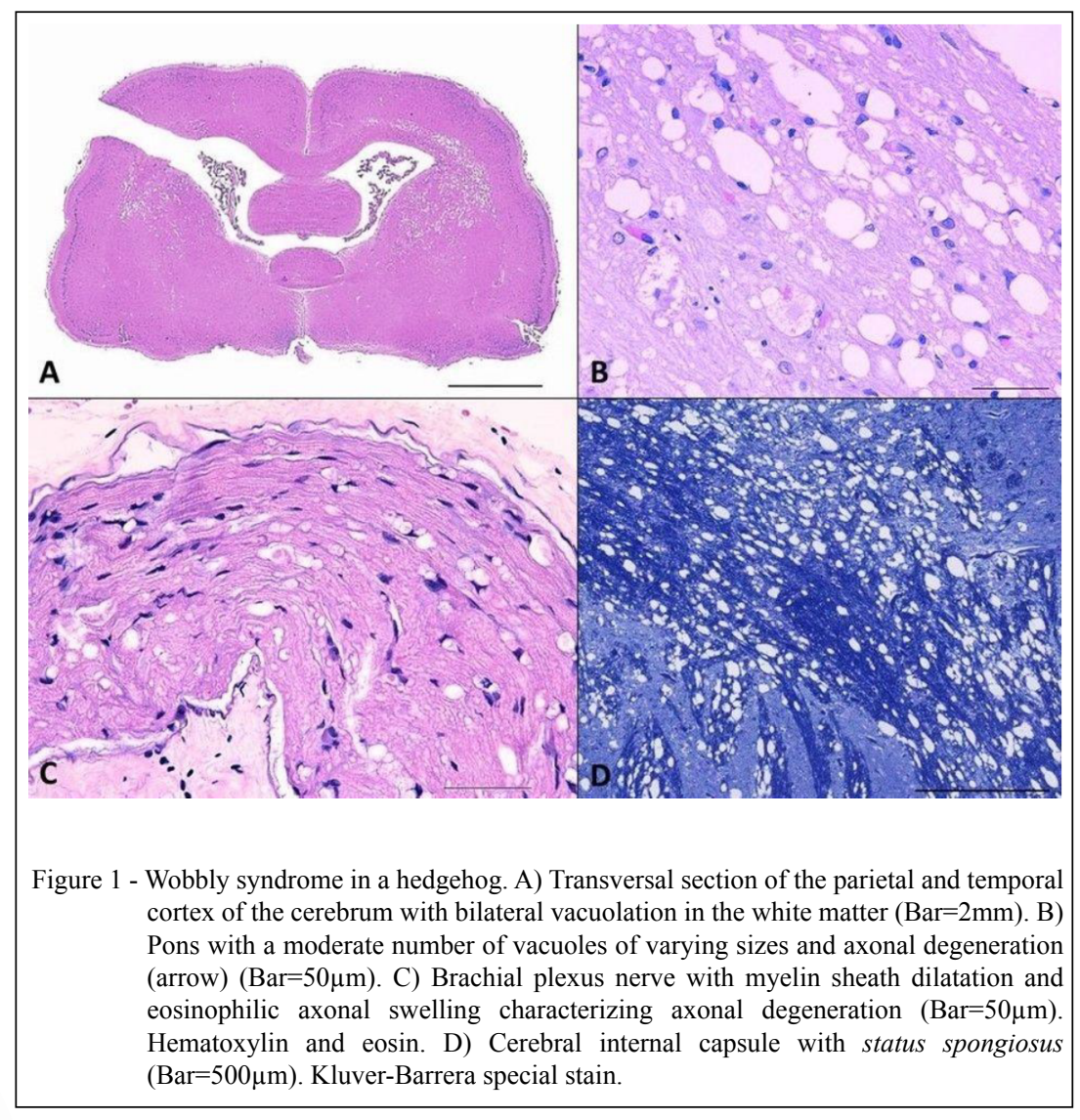

Ciência Rural, v.49, n.1, 2019. 
axons with a thinner aspect in the vacuolated areas compared to the surrounding areas. Olig- 2 revealed no changes in the number of oligodendrocytes compared with the control case, but there was a slight decrease in PLP immunostaining in the vacuolated areas (Figure 2A). There was a moderate increase in immunostaining for GFAP (Figure 2B) and a marked increase for Iba-1 in the vacuolated areas. The diagnosis of WS in the present hedgehog was based on clinical signs, accompanied by histological changes, and IHC results.

The etiology of WS in hedgehogs is still unclear, but as any disease where demyelination occurs, it is suggested that it could be acquired or genetic/hereditary (LASSMAN, 2001; DÍAZDELGADO et al., 2018). However, there is a tendency for the syndrome to occur in animals of the same lineage, strongly suggesting that the disease is hereditary (GRAESSER et al., 2006). The parents of the hedgehog from this report were siblings and this kinship may be related to the occurrence of this condition in the puppy.

Clinically, there are differential diagnoses for WS that should be considered, such as hepatic or renal encephalopathy (VANDEVELDE et al., 2012), viral infections by canine distemper virus (VIZOSO \& THOMAS, 1981), degeneration of the intervertebral disc (RAYMOND et al., 2009) and neoplasia (NAKATA et al., 2011; BURBALLA et al., 2012). The animal in this report had motor neurological deficits as well as vacuolation and demyelination of the white matter of the central and peripheral nervous system, without a concomitant inflammatory and/or neoplastic process. Furthermore, a relation between the hepatic and renal lesions was not found because of the low intensity of these lesions as well as the type and distribution of the lesions in the peripheral and CNS.

WS is confirmed by histopathological and immunohistochemical examination, where myelin loss, characterized by vacuolation of the central and peripheral white matter is followed by degeneration and axonal loss. In some cases of wobbly syndrome, neuronal degeneration has been described (GRAESSER et al., 2006; FILHO et al., 2015, DÍAZ-DELGADO et al., 2018). In our case, demyelination was confirmed by $\mathrm{KB}$ stain and $\mathrm{Nft}$ labeling confirmed a secondary axonal degeneration in these demyelinated areas. Astrocytosis confirmed by GFAP immunostaining (GRAESSER et al., 2006) and microgliosis confirmed by Iba-1 immunostaining (SOFRONIEW \& VINTERS, 2010) were also present in our case. These results characterized a multifocal reactive astrocytosis and a neuroinflammatory response due to an increase in the number of microglial cells in vacuolation sites.

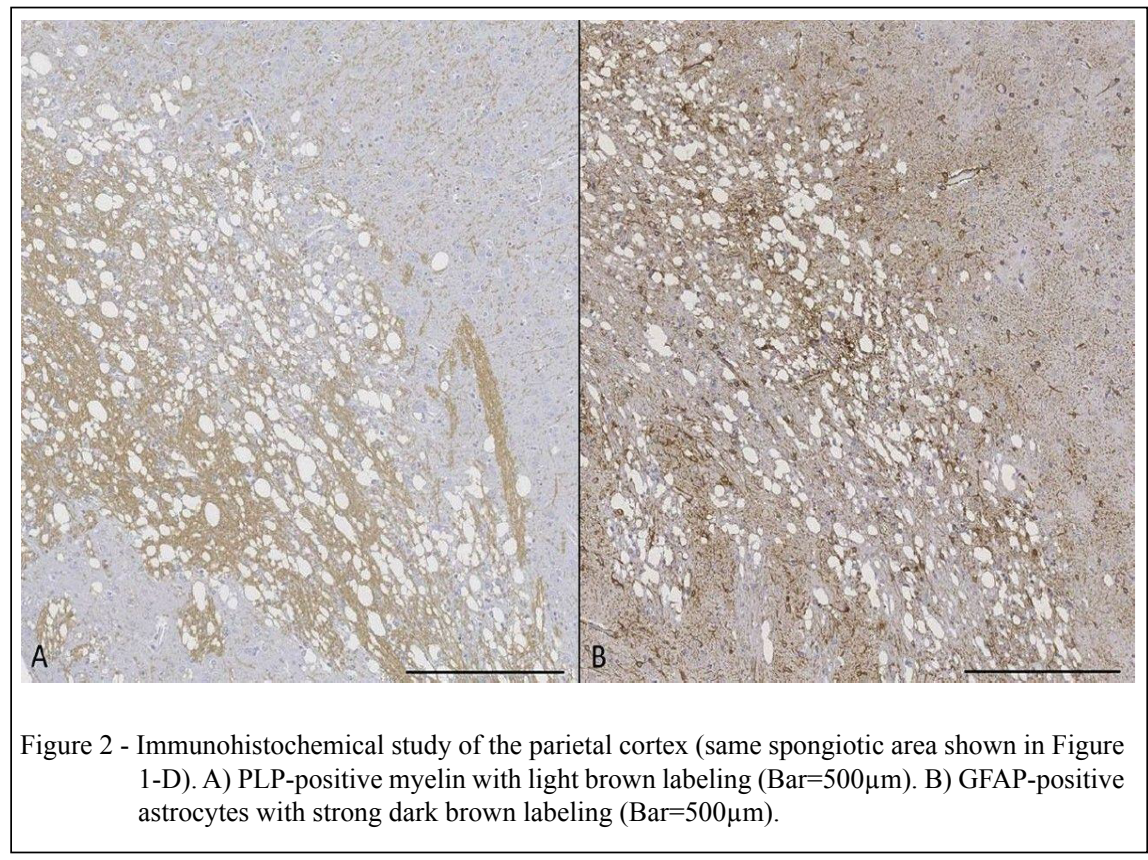

Ciência Rural, v.49, n.1, 2019. 
In our case, no changes were detected concerning the presence and number of oligodendrocytes but a mild immunopositivity was detected by PLP. Our results for PLP in the areas of vacuolation are in agreement with those observed previously in paralytic rabbits (SYPECKA \& DOMAŃSKA, 2006) and in human patients with multiple sclerosis (BØ et al., 2003).

A previous study of WS reported minimal or no lesions in the peripheral nerves (GRAESSER et al., 2006; DÍAZ-DELGADO et al., 2018). Another study of 14 cases of paralysis associated with demyelination and inflammation of the CNS in hedgehogs found no lesions on peripheral nerves (PALMER et al., 1998). Nevertheless, the findings described in our case included nerve fiber vacuolation and axonal degeneration. In the present case, the atrophy of the axial and appendicular skeletal striated musculature and the presence of anguloid myofibers without inflammatory infiltrate suggested a neurogenic origin (GRAESSER et al., 2006; DÍAZ-DELGADO et al., 2018).

WS is a neurodegenerative disease that affects hedgehogs; however, ante-mortem diagnosis is challenging. Histopathological findings were fundamental for diagnosing this case. It is currently the only means of definitive diagnosis for the disease. The white matter vacuolation is due to myelin loss and secondary axonal degeneration, related with abnormal myelin sheath organization, as demonstrated by the PLP IHC test. Therefore, although the etiology of this syndrome is still not clear, our immunohistochemical findings together with the fact that the progenitors were siblings supports our suspicion of a genetic origin affecting the PLP gene. Additional genetic studies are needed to test whether this suspicion is correct.

\section{ACNOWLEDGEMENTS}

Scholarships were provided by Conselho Nacional de Desenvolvimento Científico e Tecnológico (CNPq), Coordenação de Aperfeiçoamento de Pessoal de Nível Superior (CAPES) - Finance Code 001. Additional support was provided by Pró-Reitoria de Pesquisa da Universidade Federal de Minas Gerais (UFMG)

\section{DECLARATION OF CONFLICTING INTERESTS}

The authors declare no conflict of interest. The founding sponsors had no role in the design of the study; in the collection, analyses, or interpretation of data; in the writing of the manuscript, and in the decision to publish the results.

\section{AUTHORS' CONTRIBUTIONS}

MVLM performed the post mortem examination LBO, MVLM, WHMS and LS carried out lab tests to obtain the slides, performed the histopathology examination, captured the microscopic images and prepared the draft of the manuscript. RE supervised and coordinated all steps, revised and prepared the final version of the manuscript. MDPC and MP performed the special stain, the IHC, included these information in the results part and revised the manuscript. All authors critically revised the manuscript and approved of the final version.

\section{REFERENCES}

BØ, L. et al. Subpial demyelination in the cerebral cortex of multiple sclerosis patients. Journal Neuropathology \& Experimental Neurology, v.62, n.7, p.723-732, 2003. Available from: $<$ https:// doi.org/10.1093/jnen/62.7.723>. Accessed: Sept. 01, 2018. doi: 10.1093/jnen/62.7.723.

BURBALLA, A. et al. Splenic lymphoma with cerebellar involvement in an African hedgehog (Atelerix albiventris). Journal of Exotic Pet Medicine, v.21, p.255-259, 2012. Available from: < https://doi.org/10.1053/j.jepm.2012.06.020>. Accessed: Sept. 01, 2018. doi: 10.1053/j.jepm.2012.06.020.

DÍAZ-DELGADO, J. et al. The pathology of wobbly hedgehog syndrome. Veterinary Pathology. v.55, p.711718, 2018. Available from: <http://journals.sagepub.com/doi/ abs/10.1177/0300985818768033>. Accessed: Nov. 02, 2018. doi. org/10.1177/0300985818768033.

FILHO, K.A. et al. Síndrome de wobbly em hedgehog (Atelerix albiventris) (Wobbly Hedgehog Syndrome) - Primeiro Relato de Caso no Brasil. Revista Brasileira de Ciências Veterinárias, v.110, p.124-126, 2015. Available from: <http://www.fmv.ulisboa. pt/spcv/PDF/pdf6_2015/124-126.pdf >. Accessed: Sept. 02, 2018.

GRAESSER, D. et al. Wobbly hedgehog syndrome in African pygmy hedgehogs (Atelerix spp.). Journal of Exotic Pet Medicine, v.15, n.1, p.59-65, 2006. Available from: $<$ https://doi. org/10.1053/j.jepm.2005.11.010>. Accessed: Sep. 01, 2018. doi: 10.1053/j.jepm.2005.11.010.

IVEY, E.; CARPENTER, J.W. (2012) African hedgehogs. In: QUESENBERY, K.E.; CARPENTER, J.W. Ferrets, Rabbits and Rodents Clinical Medicine and Surgery. St. Louis: Elsevier, 2012. Cap. 30, p. 411-426.

LASSMAN, H. Classification of demyelinating diseases at the interface between etiology and pathogenesis. Current Opinion in Neurology, v.14, p.253-258, 2001. Available from: $<$ https://journals.1ww.com/co-neurology/Abstract/2001/06000/ Classification_of_demyelinating_diseases_at_the.1.asp $\mathrm{x}>$. Accessed: Sept. 02, 2018.

LENNOX, A.M. Emergency and critical care procedures in sugar gliders (Petaurus breviceps), African Hedgehogs (Atelerix albiventris), and Prairie Dogs (Cynomys spp). Veterinary Clinics of North America: Exotic Animal Practice, v.10, n.2, p.533-555, 2007. Available from: <https://doi.org/10.1016/j. cvex.2007.01.001>. Accessed: Sept. 02, 2018. doi: 10.1016/j. cvex.2007.01.001. 
SOFRONIEW, M.V.; VINTERS, H.V. Astrocytes: biology and pathology. Acta Neuropathologica, v.119, p.7-35, 2010. Available from: $<$ https://link.springer.com/article/10.1007/s00401-009-06198>. Accessed: Sept. 02, 2018.

NAKATA, M. et al. Astrocytoma in an African hedgehog (Atelerix albiventris) suspected wobbly hedgehog syndrome. Journal Veterinary Medicine Science, v.73, n.10, p.1333-1335, 2011. Available from: <https://doi.org/10.1292/jvms.10-0341> Accessed: Sept. 01, 2018. doi: 10.1292/jvms.10-0341.

PALMER, A.C. et al. Paralysis is hedgehogs (Erinaceus europaeus) associated with demyelination. Veterinary Record, v.153, p.550-552, 1998. Available from: <http://dx.doi.org/10.1136/ vr.143.20.550>. Accessed: Sept. 01, 2018. doi: 10.1136/ vr.143.20.550.

RAYMOND, J.T. et al. Intervertebral disc disease in African Hedgehogs (Atelerix albiventris): Four Cases. Journal of Exotic Pet Medicine, v.18, n.3, p.220-223, 2009. Available from:
$<$ https://doi.org/10.1053/j.jepm.2009.06.007>. Accessed: Sept. 01, 2018. doi: 10.1053/j.jepm.2009.06.007.

SYPECKA, J.; DOMAŃSKA, K. Phenotypic diversity resulting from a point mutation in a plp gene in paralytic tremor rabbit. Folia Neuropathologica, v.44, n.4, p.244-250, 2006. Available from: $<$ https://www.termedia.pl/Original-article-Phenotypic-diversityresulting-from-a-point-mutation,20,7177,0,1.html $>$. Accessed: Sept. 02, 2018.

VANDEVELDE, M. et al. Veterinary neuropathology. Essentials of theory and practice. John Wiley \& Sons, Lda. Wiley-Blackwell, United Kingdom. 2012, 216 p.

VIZOSO, A.D.; THOMAS, W.E. Paramyxoviruses of the morbilli group in the wild hedgehog Erinaceus europaeus. British Journal of Experimental Pathology, v.62, n.1, p.7986, 1981. Available from: <https://www.ncbi.nlm.nih.gov/ pmc/articles/PMC2041645/pdf/brjexppathol00109-0091.pdf>. Accessed: Sept. 02, 2018. 